\section{Nitrogen Increases Fresh Weight and Retail Value of Fraser Fir Christmas Trees}

\author{
L. Eric Hinesley ${ }^{1}$ and Layne K. Snelling ${ }^{2}$ \\ Department of Horticultural Science, North Carolina State University, Raleigh, \\ NC 27695-7609
}

C. Ray Campbell ${ }^{3}$

Agronomic Division, North Carolina Department of Agriculture and Consumer Services, Raleigh, NC 27607-6465

\section{D.K. Roten ${ }^{2}$ and Jeff Hartzog ${ }^{2}$}

Upper Mountain Research Station, Laurel Springs, NC 28644-9406

Additional index words. Abies fraseri, budset, biomass, foliage area, needle traits, shearing, leader number, retail value

\begin{abstract}
Abies fraseri (Pursh) Poir. Christmas trees were fertilized for 5 years with four levels of $\mathrm{N}\left(0,56,113\right.$, or $170 \mathrm{~kg} \cdot \mathrm{ha}^{-1}$ per year) in spring, fall, or equally split between spring and fall. Nitrogen did not affect leader length, number of leaders, or bud frequency on the upper (distal) portion of the leader. Nitrogen increased bud frequency on the lower (proximal) $20 \mathrm{~cm}$ of the leader in only 1 of 3 years of measurement. All application schedules increased the number of apical buds on branches, whereas the number of lateral buds was increased only by spring applications. Nitrogen increased tree fresh weight and retail value as well as weight, length, and surface area of needles. Foliar $\mathbf{N}$ concentrations in the fall varied with fertilization schedule, and were higher in November than in October.
\end{abstract}

Fraser fir is a valuable Christmas tree species native to western North Carolina. Trees are grown in plantations, usually at a density of $4290 \mathrm{trees} / \mathrm{ha}$ (1740 trees/acre), and are 1.8 to $2.1 \mathrm{~m}$ tall after 6-8 years. As the Christmas tree industry has expanded, fertilization practices have received increasing attention.

Numerous accounts have documented positive responses by Abies sp. to $\mathrm{N}$ fertilization (Bruns, 1973, Czapowskyj et al., 1980; Gessel and Klock, 1981; Heninger, 1981; Powers, 1981; Timmer and Stone, 1978). However, a

Received for publication 3 May 1999. Accepted for publication 16 Nov. 1999. This research was supported by the North Carolina Agricultural Research Service (NCARS), Raleigh, and the North Carolina Dept. of Agriculture and Consumer Services. We thank personnel at the Upper Mountain Research Station at Laurel Springs who helped with all phases of this study; Gary Pierce and Scott Smith (Research Technicians); Sandy Donaghy (North Carolina State Univ., Statistical Consulting Services); and Jill Sidebottom and Jerry Washington (North Carolina Coop. Extension Service) for suggestions concerning pest control and management.Mention of trade names is neither an endorsement by the agencies supporting this research nor criticism of similar unnamed products. The cost of publishing this paper was defrayed in part by the payment of page charges. Under postal regulations, this paper therefore must be hereby marked advertisement solely to indicate this fact.

${ }^{1}$ Professor.E-mail address: eric_hinesley@ ncsu.edu ${ }^{2}$ Research Technician.

${ }^{3}$ Plant/Waste/Solution Advisory Section (retired). recent study of noble fir (Abies procera Rehd.) Christmas tree plantations in Oregon and Washington found no benefit of $\mathrm{N}$ fertilization other than improved foliage color (Fletcher et al., 1998).

In North Carolina, the recommended rate of $\mathrm{N}$ for Fraser fir Christmas trees is $15 \mathrm{~g} /$ tree $\left(58 \mathrm{~kg} \cdot \mathrm{ha}^{-1}\right.$ per year) each year until trees reach $\approx 1 \mathrm{~m}$ tall, and $30-60 \mathrm{~g}$ thereafter (115 to 230 $\mathrm{kg} \cdot \mathrm{ha}^{-1}$ per year) (Shelton, 1983). Opinions differ concerning rate and timing of $\mathrm{N}$. Therefore, our objective was to evaluate the effects of different rates of $\mathrm{N}$ and application schedules on the growth and value of Fraser fir Christmas trees.

\section{Materials and Methods}

In Summer 1989, an old pasture was selected (Soil series: Chester; slope 17\%, aspect SSW) at the Upper Mountain Research Station, Laurel Springs, N.C. (lat. $36^{\circ} 24^{\prime}$ N, long. $81^{\circ} 18^{\prime} \mathrm{W} ; 1000 \mathrm{~m}$ elevation). Legumes were eliminated with selective herbicides. Rows were marked $1.8 \mathrm{~m}$ apart on the contour. In September, remaining vegetation was killed in a 45-cm strip in each row using Roundup (glyphosate). After the vegetation died, 340 $\mathrm{kg} \cdot \mathrm{ha}^{-1}$ triple super phosphate $(0 \mathrm{~N}-20 \mathrm{P}-0 \mathrm{~K})$ was broadcast, based on soil test recommendations. Sub-soiling was accomplished in October by pulling a single chisel down the centerline of each row at a depth of $45-60 \mathrm{~cm}$. Rows were tilled on the centerline to a depth of $15 \mathrm{~cm}$ (band width $\approx 75 \mathrm{~cm}$ ). Initial soil $\mathrm{pH}$ was 6.0 .
Transplants of Fraser fir (5 years old, 30 $60 \mathrm{~cm}$ tall; provenance: Mt. Rogers, Va.) were planted in late Mar. 1990. The design was a randomized complete-block with five replications, 10 treatments, and 49 trees (7 trees $\times 7$ trees; spacing: $1.5 \times 1.5 \mathrm{~m}$ ) per replication per treatment plot, and a total of 50 plots. Plots were separated by 5 -m grass buffer strips. Three rates $(56,113$, or 170 $\mathrm{kg} \cdot \mathrm{ha}^{-1} /$ year) of elemental N (source: ammonium nitrate, $33 \mathrm{~N}-0 \mathrm{P}-0 \mathrm{~K}$ ) were factorially combined with three application schedules (spring, fall or equally split between spring and fall). A control treatment received no N fertilization during the rotation. Data were recorded for 25 interior trees $(5$ trees $\times 5$ trees).

Beginning the third year, $\mathrm{N}$ was applied either in late March, late September, or both, depending on treatment schedule. During the first 4 years, fertilizer was spread uniformly by hand around the drip-line of each tree; in the last 4 years, it was broadcast. All trees within each plot were similarly fertilized.

A soil sample (composite of at least six cores from the $0-15 \mathrm{~cm}$ depth) was collected yearly in each plot, usually in September. On several occasions during the rotation, dolomitic limestone and $\mathrm{K}$ (potassium sulfate, $0 \mathrm{~N}-0 \mathrm{P}-42 \mathrm{~K}$ ) were broadcast on plots, according to soil test recommendations. Trees were sheared annually to control shape and crown density, and insect pests were controlled with standard practices. If a tree had multiple leaders (orthotropic shoots emerging from the most recent node on the primary axis), a "best" leader was selected, and the others were removed. The shoot with the most vertical orientation and the largest basal diameter was chosen.

In October or November each year, a composite sample of current-year needles was collected in each plot, using trees in two randomly selected rows. After drying for $4 \mathrm{~d}$ at $65{ }^{\circ} \mathrm{C}$ in a forced-air oven, samples were ground to a pass a 1-mm screen (20-mesh). Total $\mathrm{N}$ was determined by combustion using a Carlo Erba NA1500 analyzer (Carlo Erba Instrument Azione, Milan, Italy) (Campbell, 1992; Pella and Colombo, 1973).

The following measurements were taken each year, beginning in 1992: 1) length of best leader, 2) number of buds on the upper $7.6 \mathrm{~cm}$ and lower $20 \mathrm{~cm}$ of the best leader, and 3 ) number of orthotropic leaders or upturned branches in the top whorl.

To determine if needles were affected by $\mathrm{N}$ treatments, current-year needles were sampled in early Apr. 1997. To test "rate" effects, plots involving split applications of $\mathrm{N}$ were used. Seven trees were sampled in each plot, giving 35 trees per treatment (5 blocks $\times 7$ trees). A 2-year-old branch was selected in the upper crown, and one currentyear needle removed (abaxial side, center of internode). Needles were taped to white file cards and photocopied to capture images. While attached to cards, needles were dried for $4 \mathrm{~d}$ in a forced-air oven at $65^{\circ} \mathrm{C}$, and dry weight recorded. Length and area of each image was determined using a Monochrome 
Agvision System area meter with DIAS software (version 1.0, ca. 1989; Decagon Devices, Pullman, Wash.). Areas were multiplied by 1.145 to correct for the flattened, elliptical shape of the needles' upper (adaxial) surface (Brewer et al., 1992).

To evaluate application schedules, the aforementioned procedure was carried out in plots that received the medium $\mathrm{N}$ rate (113 $\left.\mathrm{kg} \cdot \mathrm{ha}^{-1}\right)$. Ten trees were sampled per block, yielding 50 trees per treatment for the analysis.

Bud production on leaders and branches affects tree density, value and consumer acceptability. If budset improves, it will likely increase the value of the tree. In addition, if buds are sparse, the leader must be shortened excessively to increase tree density, which can add one or more years to the harvest age. Conversely, if bud density is high, the leader can be left longer each year (more internodal branches to fill the crown), and trees reach marketable size a year or two earlier.

To evaluate budset, branches were sampled in Aug. 1997 from: 1) control plots; 2) plots where $\mathrm{N}$ was equally divided between spring and fall (rates $=56,113$, or 170 $\mathrm{kg} \cdot \mathrm{ha}^{-1}$ per year); and 3) plots that received the medium rate of $\mathrm{N}\left(113 \mathrm{~kg} \cdot \mathrm{ha}^{-1}\right)$ in spring, fall or equally split between spring and fall. Four branch tips (10 cm long) were taken from each sample tree, two from the second whorl below the current-year leader and two from mid-crown (1-1.3 $\mathrm{m}$ above the soil surface). The crown is the aerial part of the tree. Within each plot, shoots were grouped by crown position, and buds were counted in the terminal cluster and along the distal 10 $\mathrm{cm}$, excluding the terminal cluster.

In Fall 1997, retail value was estimated independently by three experienced marketers of Fraser fir Christmas trees. Commercial heights (height after shearing) were measured to assist in determining tree value. Prior to harvest in Dec. 1997, the width of the lower crown was measured horizontally in two directions $\left(90^{\circ}\right.$ opposition), and the values were averaged. Following cutting, trees were baled within 10 min of cutting, and weighed. Average trunk diameter, measured in two directions $\left(90^{\circ} \mathrm{op}-\right.$ position) $10 \mathrm{~cm}$ above the basal cut, was recorded. The resulting number was used to determine stem cross-sectional area.

Data were analyzed with GLM and regression procedures (SAS Institute, 1989). This experiment had 10 treatments, in a $3 \times 3$ factorial (rates $\times$ dates), the tenth as a control. Thus, there were nine degrees of freedom (df) for treatments, eight of which were from the factorial. A linear contrast ( $1 \mathrm{df}$ ) was used to compare the mean for the control treatment (no N) with the collective mean for trees fertilized with N. Thus, the "rate" effect was based on the range $56-170 \mathrm{~kg} \cdot \mathrm{ha}^{-1}$ of $\mathrm{N}$ applied per year, excluding the control. The linear contrast was sometimes significant, but not the 'rate' effect, meaning that $56 \mathrm{~kg} \cdot \mathrm{ha}^{-1}$ of $\mathrm{N}$ was beneficial, but 113 or $170 \mathrm{~kg}$ gave little added benefit. When the rate effect was significant, it was partitioned into linear and quadratic components.

\section{Results and Discussion}

Nitrogen fertilization had slight to moderate effects on some, but not all, growth measurements (Table 1). Leader length was not affected by $\mathrm{N}$ fertilization (data not shown), nor was the number of orthortopic which averaged 2.3 to 2.6 per tree (data not shown). Nitrogen application increased crown width, but there was no "rate" or "seasonal" effect (Table 1). Crown closure, combined with annual shearing, causes crown width to converge to a value equal to the average distance between trees.

Nitrogen fertilization increased average trunk diameter by $0.85 \mathrm{~cm}(19 \%$ increase in cross-sectional area) (Table 1), but again there was no rate or seasonal effect. Similarly, average commercial height was $\approx 2.3$ $\mathrm{m}$, with no treatment differences of practical importance (data not shown). Means were within a single, $0.3 \mathrm{~m}$, wholesale height class (e.g., 2.12 to $2.43 \mathrm{~m}$ ), where trees normally have the same wholesale price. Retail value can vary greatly within a class (Arnold et al., 1995 ).

Tree fresh weight increased linearly with increasing $\mathrm{N}$ (Table 1) (Wt in $\mathrm{kg}=22.14+$ $0.056 \times$ Rate Range $=0-170 \mathrm{~kg} \cdot \mathrm{ha}^{-1} /$ year $; R^{2}$ $=0.26 ; P \leq 0.01)$. Fertilized trees were $13 \%$ to $22 \%$ heavier than controls, and their mean retail value was $\approx \$ 7.00$ more $(20 \%$ increase) than that of nonfertilized trees (Table 1, Cont.

Table 1. Analysis of data for dimensions, retail value and bud counts of Fraser fir Christmas trees fertilized with various levels of $\mathrm{N}$ and different schedules of application.

\begin{tabular}{|c|c|c|c|c|c|c|c|c|c|}
\hline \multirow{2}{*}{$\begin{array}{l}\text { Source or } \\
\text { treatment }^{2}\end{array}$} & & \multicolumn{5}{|c|}{ Variable $^{y}$} & \multicolumn{3}{|c|}{ Buds per $\mathrm{cm}^{\mathrm{y}}$} \\
\hline & & $\overline{\mathrm{Ht}}$ & Width & Diam. & $\mathrm{Wt}$ & $\overline{\text { Value }}$ & 1994 & 1995 & 1996 \\
\hline Source & $\underline{\mathrm{df}}$ & \multicolumn{8}{|c|}{ Significance of F } \\
\hline Rate & $\overline{2}$ & NS & NS & NS & $*$ & NS & NS & NS & NS \\
\hline Linear & 1 & --- & --- & --- & $*$ & --- & --- & --- & --- \\
\hline Quadratic & 1 & --- & --- & --- & NS & --- & --- & --- & --- \\
\hline Season & 2 & $*$ & NS & NS & NS & NS & NS & $*$ & NS \\
\hline Rate $\times$ season & 4 & $*$ & NS & NS & NS & NS & NS & NS & NS \\
\hline Cont. vs. N & 1 & NS & $*$ & $* *$ & $* *$ & $* *$ & $* *$ & $* *$ & NS \\
\hline Error & 36 & --- & --- & --- & --- & --- & --- & --- & --- \\
\hline Treatment & No. Plots & \multicolumn{8}{|c|}{ Means } \\
\hline Control & 5 & $\begin{array}{l}-- \\
--\end{array}$ & 1.42 & 9.19 & 20.95 & 34.64 & $0.42 \mathrm{a}^{\mathrm{x}}$ & $0.33 \mathrm{a}$ & $0.28 \mathrm{a}$ \\
\hline $\mathrm{N}$ & 45 & --- & 1.47 & 10.04 & 24.71 & 41.46 & --- & --- & --- \\
\hline Spring & 15 & --- & -- & -- & -- & -- & $0.45 \mathrm{~b}$ & $0.35 \mathrm{ab}$ & $0.30 \mathrm{a}$ \\
\hline Fall & 15 & --- & --- & --- & --- & --- & $0.45 \mathrm{~b}$ & $0.38 \mathrm{c}$ & $0.28 \mathrm{a}$ \\
\hline Spring \& Fall & 15 & --- & --- & --- & --- & --- & $0.45 \mathrm{~b}$ & $0.37 \mathrm{bc}$ & $0.31 \mathrm{a}$ \\
\hline
\end{tabular}

"Season: Spring (late March); Fall (late September). "Cont. vs. N" compares the control (no N) to the mean for all trees that received N. Annual rates: 0, 56, 113, and $170 \mathrm{~kg} \cdot \mathrm{ha}^{-1}$.

${ }^{\mathrm{y}} \mathrm{Ht}$. = commercial height $(\mathrm{m}) ;$ Width $=$ crown width at base $(\mathrm{m}) ;$ Diam. $=$ stem diameter $(\mathrm{cm}) 10 \mathrm{~cm}$ above harvest cut; $\mathrm{Wt}=$ total fresh weight $(\mathrm{kg})$; Value = average retail value $(\$)$, based on three appraisals; bud counts were for the lower (proximal) $20 \mathrm{~cm}$ of the best leader.

${ }^{x}$ Mean separation within columns by Duncan's multiple range test, $P \leq 0.05$.

Ns, *, ***Nonsignificant or significant at $P \leq 0.05$ or 0.01 , respectively.

Table 2. Effect of rate and season of application of $\mathrm{N}$ on budset and needle traits of Fraser fir Christmas trees in 1997.

\begin{tabular}{|c|c|c|c|c|c|c|c|}
\hline \multirow[b]{2}{*}{ Treatments } & \multirow[b]{2}{*}{ Plots } & \multicolumn{3}{|c|}{ Budset $^{2}$} & \multicolumn{3}{|c|}{ Needle trait ${ }^{\mathrm{y}}$} \\
\hline & & Apical & Lateral & Total & Dry wt (mg) & Length $(\mathrm{mm})$ & Area $\left(\mathrm{cm}^{2}\right)$ \\
\hline \multicolumn{8}{|c|}{ Season of application ${ }^{x}$} \\
\hline Control & 5 & $3.8 \mathrm{a}^{\mathrm{w}}$ & $5.8 \mathrm{a}$ & $9.6 \mathrm{a}$ & $12.7 \mathrm{a}$ & $22.6 \mathrm{a}$ & $0.44 \mathrm{a}$ \\
\hline Spring & 5 & $4.0 \mathrm{~b}$ & $6.5 \mathrm{~b}$ & $10.5 \mathrm{~b}$ & $14.3 \mathrm{~b}$ & $23.5 \mathrm{ab}$ & $0.62 \mathrm{c}$ \\
\hline Fall & 5 & $4.1 \mathrm{~b}$ & $5.6 \mathrm{a}$ & $9.7 \mathrm{a}$ & $14.1 \mathrm{~b}$ & $24.4 \mathrm{bc}$ & $0.57 \mathrm{~b}$ \\
\hline Spring \& Fall & 5 & $4.1 \mathrm{~b}$ & $5.9 \mathrm{a}$ & $10.0 \mathrm{a}$ & $14.5 \mathrm{~b}$ & $24.6 \mathrm{c}$ & $0.56 \mathrm{~b}$ \\
\hline Season & & $\overline{\mathrm{NS}}$ & $-\bar{*}$ & $-\bar{*}$ & --- & $-\frac{-}{\mathrm{NS}}-$ & $--\bar{*}-$ \\
\hline Cont. vs. N & & $* *$ & NS & $* *$ & $* *$ & $* *$ & $* *$ \\
\hline \multicolumn{8}{|c|}{ Rate of application $\left(\mathrm{kg} \cdot \mathrm{ha} a^{-l}\right)^{v}$} \\
\hline 0 & 5 & 3.8 & 5.8 & 9.6 & 12.7 & 22.6 & 0.44 \\
\hline 56 & 5 & 4.0 & 5.9 & 9.9 & 14.3 & 24.7 & 0.53 \\
\hline 113 & 5 & 4.1 & 5.9 & 10.0 & 14.5 & 24.6 & 0.56 \\
\hline 170 & 5 & 4.1 & 5.8 & 9.9 & 15.1 & 25.8 & 0.52 \\
\hline Linear & & $-\bar{*}$ & $-\frac{-}{N S}$ & --- & $--\overline{* *}-$ & $-\overline{* *}-$ & $--\bar{*}-$ \\
\hline Quad & & NS & NS & NS & NS & NS & $* *$ \\
\hline Cont. vs. N & & $* *$ & NS & NS & $* *$ & $* *$ & $* *$ \\
\hline
\end{tabular}

${ }^{\mathrm{z}}$ Apical $=$ terminal + subterminal buds at apex of branch; lateral $=$ buds on the distal $10 \mathrm{~cm}$ of the branch, excluding the apex.

y Current-year needles.

"Season: Spring (late March); Fall (late September). Annual rate = $113 \mathrm{~kg} \cdot \mathrm{ha}^{-1}$. "Cont. vs. N" compares the control mean with the average for all trees that received $\mathrm{N}$.

'Mean separation within columns by Duncan's multiple range test, $P \leq 0.05$.

${ }^{\vee}$ Equally split between Spring and Fall.

Ns, *, ** Nonsignificant or significant at $P \leq 0.05$ or 0.01 , respectively. 
vs. N, $P \leq 0.01$ ), but the rate and season effects were nonsignificant. Mean retail value for the $170-\mathrm{kg}$ rate was $\$ 42.19$ vs. $\$ 40.71$ for $56-\mathrm{kg}$ rate.

Budset on the lower (proximal) $20 \mathrm{~cm}$ of the leader was affected by season of application in only 1 of 3 years from 1994 through 1996 (Table 1). During that time, bud counts decreased from 0.42 to 0.28 buds $/ \mathrm{cm}$ in control trees, and 0.45 to 0.30 buds $/ \mathrm{cm}$ in fertilized trees (Table 1). The decline appeared to result from reduced phosphorus supply late in the rotation (data not shown). In 1994 and 1995, trees fertilized with $\mathrm{N}$ averaged 0.45 and 0.36 buds $/ \mathrm{cm}$, respectively, on the lower leader, compared with 0.42 and 0.33 buds for controls (Table 1).

Applying $\mathrm{N}$ in spring increased both lateral and total buds on branches (Table 2). The number of apical buds on branches increased linearly with increasing N. Differences were small, but if compounded annually for 6 to 8 years, could affect branch production. Nitrogen rate did not affect lateral budset.

An increase in the size of current-year needles is a good short-term indicator of improved growth in response to fertilization (Timmer and Stone, 1978). Nitrogen increased dry weight, length, and area of current-year needles (Table 2). The longest needles occurred in plots receiving all or part of the $\mathrm{N}$ in the fall, whereas spring applications increased area per needle. Needle dry weight and length increased linearly with $\mathrm{N}$ application; trees that received $170 \mathrm{~kg} \cdot \mathrm{ha}^{-1}$ (split between spring and fall) had needles $19 \%$ heavier and $14 \%$ longer than did controls (Table 2). Needle area was maximum at $113 \mathrm{~kg} \cdot \mathrm{ha}^{-1}$. We do not know if larger average needle size was indicative of greater leaf area index. $\mathrm{N}$ increased trunk diameter, so probably also increased foliage mass, given the allometric relationship between stem diameter and the weight of various biomass components (Hinesley and Wright, 1989).

Foliar $\mathrm{N}$ concentrations in October and November were lowest when $\mathrm{N}$ was applied only in spring, 6 months before sampling (Fig. 1). Foliar $\mathrm{N}$ concentrations were higher $(P \leq 0.01)$ when $\mathrm{N}$ was applied partly or entirely in September, 1-2 months before sampling. Maximum concentrations occurred when all the $\mathrm{N}$ was applied in fall. Rates of $\mathrm{N}$ up to $113 \mathrm{~kg} \cdot \mathrm{ha}^{-1}$, applied in spring, increased foliar $\mathrm{N}$ concentration in fall, but higher rates had no additional effect (Fig. 1). Concentra-

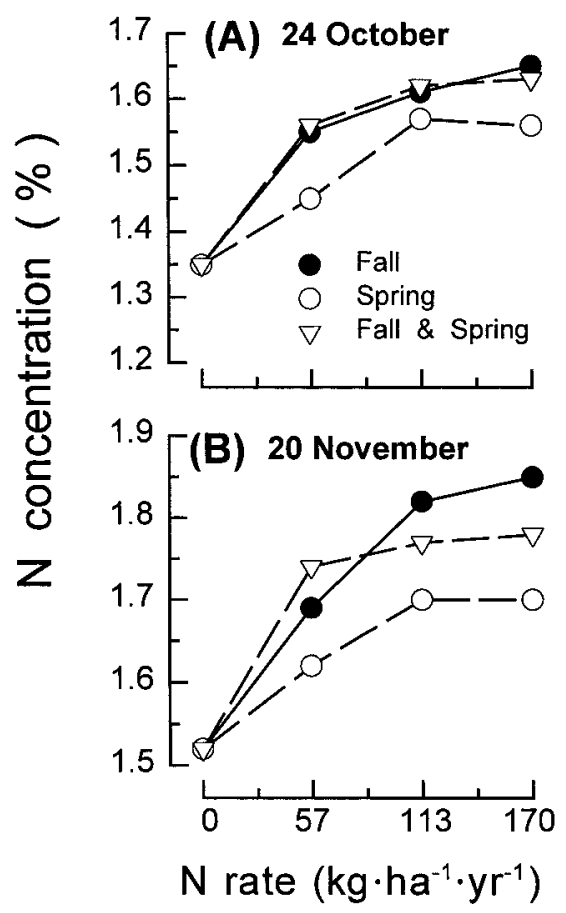

Fig. 1. Nitrogen concentration in current-year foliage of Fraser fir Christmas trees in (A) Oct. and (B) Nov. 1996 in response to season of application and rate of application. Legend: $(\bigcirc)$ applied in spring (late March); (O) applied in fall (late September); $(\nabla)$ and equally split between spring and fall. Annual rates: $0,56,113$, or $170 \mathrm{~kg} \cdot \mathrm{ha}^{-1}$. Basis: five plots (125 trees) for each symbol.

tions averaged $|0.2 \%|$ higher $(P \leq 0.01)$ in November than in October. Even though time of application affected foliar $\mathrm{N}$ concentrations, it had no significant long-term effect on growth or retail value (Table 1).

Based on these results, time of application of $\mathrm{N}$ was not critical. Further, recommending a specific rate is difficult, although some $\mathrm{N}$ was better than none. For several growth indices, including retail value, little was gained by using more than $56 \mathrm{~kg} \cdot \mathrm{ha}^{-1}$ annually. Tree fresh weight at time of harvest increased linearly with $\mathrm{N}$ rate, although variability was large. A rate of $113 \mathrm{~kg} \cdot \mathrm{ha}^{-1}(26 \mathrm{~g}$ per tree $\approx 1$ ounce) appears adequate. The quantity of $\mathrm{N}$ received in atmospheric deposition is unknown. Harvesting begins when trees reach $\approx 1.8 \mathrm{~m}$, usually spans 3 years, and is heaviest the second year. With reduced stocking as a consequence of harvesting, fer- tilization is likely to be on a per-tree basis rather than a per unit area basis.

\section{Literature Cited}

Arnold, R.J., J.B. Jett, and W.T. Huxster. 1995 Relationship of USDA grade and wholesale value to retail value in Fraser fir Christmas trees. HortScience 30:369-373.

Brewer, J.F., L.E. Hinesley, and L.K. Snelling. 1992. Foliage attributes for current-year shoots of Fraser fir. HortScience 270:920-925.

Bruns, P.E. 1973. Cultural practices, fertilizing and foliar analysis of balsam fir Christmas trees. New Hampshire Agr. Expt. Sta. Bul. 501.

Campbell, C.R. 1992. Determination of total nitrogen in plant tissue by combustion, p. 21-23. In Plant analysis procedures for the Southern Region of the United States. Southern Coop. Series Bul. 368.

Czapowskyj, M.W., L.O. Safford, and R.D. Briggs. 1980. Foliar nutrient status of young red spruce and balsam fir in a fertilized stand. U.S. Dept. Agr., Forest Serv., Northeastern Forest Expt. Sta. Res. Paper NE-457.

Fletcher, R., C. Landgren, S. Webster, and M. Bondi. 1998. Fertilizing noble fir. Christmas Tree Lookout 31(1):21-23, 26-28.

Gessel, S.P. and G.O. Klock. 1981. Mineral nutrition of true fir, p. 77-83. In: C.D. Oliver and R.M. Kenady (eds.). Proc. Biol. Mgt. of True Fir in the Pacific Northwest Symp., 24-26 Feb. 1981. Seattle-Tacoma, Wash., U.S. Dept. Agr., Forest Serv., Pacific Northwest Forest and Range Expt. Sta.

Heninger, R.L. 1981. Response of Abies concolor to intensive management, p. 319-323. In: C.D Oliver and R.M. Kenady (eds.). Proc. Biol. Mgt. of True Fir in the Pacific Northwest Symp. 24-26 Feb. 1981, Seattle-Tacoma, Wash., U.S Dept. Agr., Forest Serv., Pacific Northwest Forest and Range Expt. Sta.

Hinesley, L.E. and R.D. Wright. 1989. Biomass and nutrient accumulation in Fraser fir Christmas trees. HortScience 24:280-282.

Pella, E. and B. Colombo. 1973. Study of carbon, hydrogen and nitrogen determination by combustion-gas chromatography. Mirochimae Acta 1973:697-719.

Powers, R.F. 1981. Response of California true fir to fertilization, p. 95-101. In: S.P. Gessel, R.M. Kennedy, and W.A. Atkinson (eds.). Proc. Forest Fertilization Conf., Univ. Washington, Inst. Forest Res. Contr. 40

SAS Institute. 1989. SAS/STAT user's guide. Version $6,4^{\text {th }}$ ed. SAS Inst., Cary, N.C.

Shelton, J.E. 1983. Fertilizing Fraser fir Christmas trees. North Carolina Coop. Ext. Serv., Christmas Tree Notes CTN-010.

Timmer, V.R. and E.L. Stone. 1978. Comparative foliar analysis of young balsam fir fertilized with nitrogen, phosphorus, potassium, and lime. J. Soil Sci. Soc. Amer. 42:125-130. 